\title{
Prevention of Shaken Baby Syndrome Among High-Risk Neonates: Program Implementation and Evaluation
}

Rebecca Tortolano, DNP, MS, RN, Michelle E. Neuman, DNP, $R N$, APN, PPCNP-BC, Shannon D. Simonovich, PhD, RN

\begin{abstract}
:
Background: Studies suggest that the implementation of highquality education and support services for caregivers may reduce the incidence of unplanned harm to infants and young children under high-stress circumstances.

Purpose: This pilot study evaluates the usefulness of the Period of PURPLE Crying program in a high-acuity NICU at The University of Chicago Comer Children's Hospital based on six measurable objectives.

Methods: The pilot study utilized a Likert-style pretest-posttest survey design to evaluate how NICU nurses perceived the Period of PURPLE Crying program. Nurses were educated on the program content during an in-service to teach participants how to utilize the Period of PURPLE Crying program materials to support and educate families about Shaken Baby Syndrome (SBS).

Results: The intervention effectively increased nursing confidence in delivering the SBS and Abusive Head Trauma (AHT) education and increased accessibility to available resources pertaining to SBS and AHT. Questions pertaining specifically to the Period of PURPLE Crying presented exclusively on the post-test were met with an overwhelmingly positive response, with the majority $(n=33,97 \%)$ of respondents agreeing that the intervention was useful in standardizing SBS education, providing meaningful, effective information on this topic area, and delivering SBS and AHT information promptly.
\end{abstract}

\section{"The Centers for Disease Control and Prevention (CDC) reports previously describe how "excessive frustration} and exhaustion can lead individuals to a breaking point," leading to Shaken Baby Syndrome (SBS) and Abusive Head Trauma (AHT) in infants (n.d., p. 4) (1)."

\section{Introduction}

The Centers for Disease Control and Prevention (CDC) reports previously describe how "excessive frustration and exhaustion can lead individuals to a breaking point," leading to Shaken Baby Syndrome (SBS) and Abusive Head Trauma (AHT) in infants (n.d., p. 4) (1). Implementing high-quality education related to SBS and AHT coupled with support services for caregivers may reduce the

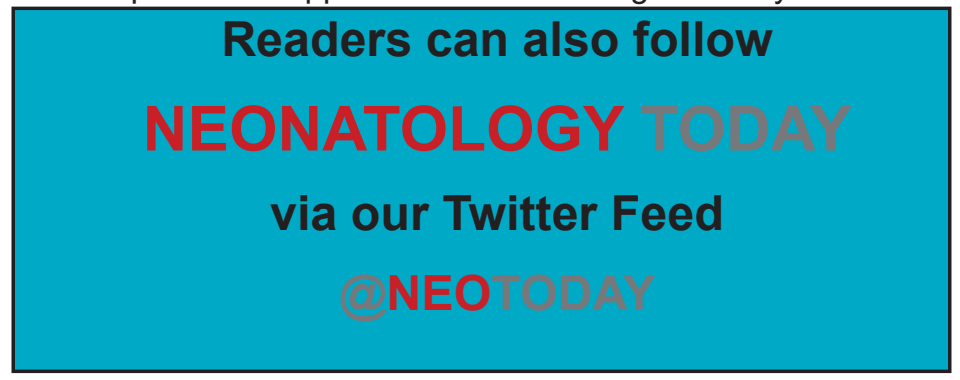

incidence of unplanned harm to infants and young children under high-stress circumstances.

\section{Incidence}

Shaken baby syndrome (SBS) is the leading cause of child abuserelated deaths in the United States (U.S.) and most often occurs in infants less than six months of age (National Center on Shaken Baby Syndrome, 2020) (2). Approximately 1,300 cases are reported each year in the U.S., with nearly $80 \%$ of survivors suffer long-term disabilities, and it proves fatal for one out of four victims (National Center on Shaken Baby Syndrome, 2020) (2). Unfortunately, data on this problem is likely underestimated as many cases remain unreported and undiagnosed (National Center on Shaken Baby Syndrome, 2020) (2). Abuse of this nature occurs when an infant's caregiver becomes excessively frustrated, with a higher incidence among those with disproportionate hardships or relationship problems that challenge coping methods (New York State Department of Health, 2010) (3). Other risk factors include those with unrealistic expectations related to normal infant behaviors, individuals that were abused or neglected as a child, domestic violence victims, single parents, preterm infants, children with disabilities, multiples, infants less than six months old, and infants

"The Period of PURPLE Crying program referred to throughout this publication, and much of the literature to date as the PURPLE program is an education program aimed to reduce the incidence of SBS and AHT through education and caregiver support during the period of increased infant crying (National Center on Shaken Baby Syndrome, 2020) (2)."

that cry inconsolably frequently (CDC, n.d.) (1).

\section{Prevention}

The Period of PURPLE Crying program referred to throughout this publication, and much of the literature to date as the PURPLE program is an education program aimed to reduce the incidence of SBS and AHT through education and caregiver support during the period of increased infant crying (National Center on Shaken Baby Syndrome, 2020) (2). A study in British Columbia evaluated a sample of 354,477 parents and concluded that the PURPLE program effectively reduced hospital admissions related to SBS and $\mathrm{AHT}$ by $35 \%$ for children ages two years and under over an eight-year period (Barr et al., 2019) (4). This hallmark study emphasizes the value of widespread adoption of standardized, preventative education related to SBS and AHT. Another large-scale study conducted in North Carolina across 86 healthcare entities found that $90 \%$ of parents receiving the PURPLE program materials recalled the main constructs two months after having received the intervention and reported an increase in behaviors such as walking away when the infant is inconsolable (Nocera et al., 2016) 
(5).

Despite these findings, just eighteen states across the U.S. have adopted the program statewide; see figure 1 in Appendix C (National Center on Shaken Baby Syndrome, 2021) (2). The universal adoption of this program among healthcare and community settings across the nation may improve coping methods for parents and caregivers, offer ongoing support, and reduce the incidence of SBS and AHT.

\section{Cost Implications:}

The cost of SBS and AHT per case accounts for millions in healthcare spending (National Center on Shaken Baby Syndrome, 2020) (2). Visits to the emergency department are one of the key drivers of cost for SBS and AHT. Barr et al. (2015) (6) found that the implementation of the PURPLE program in British Columbia decreased E.D. visits related to crying episodes for well babies by $29.5 \%$. This program contributes to better health outcomes for families and reduces the overall cost of such visits for the healthcare system.

\section{Study Purpose:}

The purpose of this project was to evaluate the usefulness of the PURPLE program in a high-acuity Neonatal Intensive Care Unit (NICU) at The University of Chicago Comer Children's Hospital. Before implementing this pilot study, SBS and AHT were routinely discussed as a part of patient education; however, this practice was carried out with minimal guidance, standardization, or clearly defined objectives.

\section{Methods}

\section{Study Design:}

The study utilized a Likert-style pretest-posttest survey design to evaluate how the PURPLE program was perceived by NICU nurses who agreed to utilize the PURPLE program content to educate parents and caregivers. The Likert scale ranged from one (strongly disagree) to seven (strongly agree). See Appendix A for complete survey content. Surveys were developed for this study and distributed using the Qualtrics software. The proposal was approved by the University of Chicago Institutional Review Board (IRB) as well as DePaul University's IRB. The University of Chicago's IRB served as the lead site for overseeing this project. IBM SPSS statistics software was used to analyze data.

\section{Implementation:}

Recruitment was completed by following a script asking nurses to partake in an in-service education aimed to teach participants how to utilize the PURPLE program materials to educate families about SBS. At the start of the in-service presentation, participants completed a confidential, Likert-style pre-intervention survey on an iPad or personal smartphone device that evaluated their perception of SBS, knowledge surrounding this topic area, and demographics. The in-service education reviewed the most common cause of SBS and AHT, timeframes of increased infant crying, and data on the incidence of such trauma in correlation with periods of increased infant crying. Nurses were asked to give parents and caregivers the PURPLE program pamphlet, review the education and direct them to the smartphone application to watch the program's video content. After delivering the intervention for approximately four to six weeks, participants received the postintervention survey link via email or text message with the same six Likert-style questions on the pre-intervention survey plus an additional three questions specific to the PURPLE program content. Participants were given a link to a free CEU related to the program content after completion of the study as an appreciation for participating in this project.

\section{Resources:}

The purchase of the PURPLE program materials was required to deliver this project. The cost of these materials was $\$ 2.00$ per pamphlet and app code couplet. Five hundred copies of these materials were purchased for a total cost of $\$ 1,000$.

\section{Measures:}

Measurable objectives for this project included: (1) nursing knowledge about SBS and AHT (pretest-posttest question one), (2) nursing confidence in delivering SBS and AHT education (pretestposttest question two), (3) accessibility to resources related to SBS and AHT (pretest-posttest question six), (4) functionality and efficacy of SBS/AHT education (pretest-posttest question four, post-test questions eight and nine), (5) perception of the value of SBS and AHT education in the NICU (pretest-posttest questions three and five), and (6) message consistency when delivering education about SBS and AHT (post-test question seven). See Appendix A for complete survey content used to measure these

\section{"After delivering the intervention for approximately four to six weeks, participants received the post- intervention survey link via email or text message with the same six Likert- style questions on the pre-intervention survey plus an additional three questions specific to the PURPLE program content."}

objectives.

\section{Results}

The study results are summarized in this section. Each participant did not respond to every question on the pre-test and post-test surveys. See Appendix B for all frequencies and means.

\section{Study Sample \& Setting:}

Data were collected from February to April 2021. Among the participants in this study, 47 individuals responded to the pre-test survey, but only 34 participants responded to the post-test for a response rate of $72 \%$. The demographic data of participants are detailed in Appendix B, Table 1.

\section{Nursing Knowledge:}

The majority ( $n=44,93.6 \%)$ of respondents on the pre-test answered positively to "I feel knowledgeable when it comes to shaken baby syndrome," with a mean score of 5.70 . Similarly, the majority $(n=33,97 \%)$ of post-test respondents agreed to a slightly higher degree, with a calculated mean score of 6.0. Despite this increase in the mean score, comparative analysis using the Wilcoxon matched-pairs test determined this change was not statistically significant $(p=.792)$.

\section{Nursing Confidence:}

The majority ( $n=40,86.9 \%)$ of pre-test respondents answered, "I feel comfortable discussing SBS with parents and caregivers of NICU infants," with an overall agreeable response and a mean score of 5.61. The majority ( $n=33,97.1 \%)$ of post-test respondents reported an increase in confidence, with a calculated mean score of 6.24. Comparative analysis using the Wilcoxon matched-pairs test confirmed this change to be statistically significant $(p=.016)$, 


\section{Appendix A}

Survey

Age: $\quad 20-30$

$31-40$

$41-50$

$51-60$

$61-70$

$71-80$

Gender: Male $\quad$ Female Other

Prefer not to answer

Education Level: Associates Degree Bachelor's Degree

Master's Degree Doctoral Degree

Years of experience as an RN: $\quad 0-5$

6-10 11-15

16-20

21-25 26-30 30+

Years of Experience in the NICU: 0-5

6-10

$11-15$

$16-20 \quad 21-25 \quad 26-30 \quad 30+$

Shift: $7 a-7 p \quad 7 p-7 a$ other

How often do you complete discharge teaching: Never

Seldom Sometimes Often

** Included on post-test only

\begin{tabular}{|c|c|c|c|c|c|c|c|}
\hline & $\begin{array}{l}1 \text { (1) } \\
\text { Strongly } \\
\text { Disagree }\end{array}$ & $\begin{array}{l}\text { (2) } \\
\text { Disagree }\end{array}$ & $\begin{array}{l}\text { (3) } \\
\text { Somewhat } \\
\text { Disagree }\end{array}$ & $\begin{array}{l}\text { (4) } \\
\text { Neutral }\end{array}$ & $\begin{array}{l}\text { (5) } \\
\text { Somewhat } \\
\text { Agree }\end{array}$ & $\begin{array}{l}(6) \\
\text { Agree }\end{array}$ & $\begin{array}{l}(7) \\
\text { Strongly } \\
\text { Agree }\end{array}$ \\
\hline $\begin{array}{l}\text { 1. I feel knowledgeable when it comes to } \\
\text { shaken baby syndrome }\end{array}$ & & & & & & & \\
\hline $\begin{array}{l}\text { 2. I feel comfortable discussing shaken baby } \\
\text { syndrome with parents and caregivers of NICU } \\
\text { infants }\end{array}$ & & & & & & & \\
\hline $\begin{array}{l}\text { 3. NICU nurses should be providing shaken } \\
\text { baby syndrome education during discharge } \\
\text { teaching }\end{array}$ & & & & & & & \\
\hline $\begin{array}{l}\text { 4. Time constraints during discharge are a } \\
\text { major barrier to discussing shaken baby } \\
\text { syndrome (i.e., too much other education to } \\
\text { provide, not enough time, too many other tasks } \\
\text { to accomplish) }\end{array}$ & & & & & & & \\
\hline $\begin{array}{l}\text { 5. Providing education about shaken baby } \\
\text { syndrome in the NICU is useful in preventing } \\
\text { unplanned harm to an infant }\end{array}$ & & & & & & & \\
\hline $\begin{array}{l}\text { 6. I am aware of available resources for } \\
\text { families and caregivers about shaken baby } \\
\text { syndrome }\end{array}$ & & & & & & & \\
\hline $\begin{array}{l}\text { 7. The Period of PURPLE Crying program was } \\
\text { helpful in standardizing shaken baby } \\
\text { syndrome education on our unit* }\end{array}$ & & & & & & & \\
\hline $\begin{array}{l}\text { 8. The Period of PURPLE Crying program } \\
\text { provides effective, meaningful education about } \\
\text { shaken baby syndrome }\end{array}$ & & & & & & & \\
\hline $\begin{array}{l}\text { 9. The Period of PURPLE Crying program } \\
\text { provides education about shaken baby } \\
\text { syndrome in a timely manner** (i.e., able to } \\
\text { provide SBS education in a reasonable amount } \\
\text { of time within discharge teaching) }\end{array}$ & & & & & & & \\
\hline
\end{tabular}


concluding that the intervention effectively increased nursing confidence in discussing SBS and AHT with families and caregivers.

\section{Resource Accessibility:}

In response to "I am aware of available resource for families and caregivers about shaken baby syndrome," pre-test responses were largely mixed with a mean score of 3.85 and only a $42.6 \%$ agreeable response. Posttest responses reflected a significant change, with a mean score of 5.97. Wilcoxon matched-pairs confirmed that this change was statically significant $(p=<.001)$, concluding that intervention effectively increased SBS and AHT resource awareness for nurses in the study.

\section{Functionality and Efficacy of SBS/AHT Education:}

Just over half $(n=32,68 \%)$ of pre-test respondents agreed that "time constraints during discharge are a major barrier to discussing shaken baby syndrome," with a calculated mean score of 4.83. Posttest responses found that nurses felt more strongly about time constraints as a barrier to SBS education post-intervention, with $76.4 \%$ of respondents reporting agree or strongly agree and a mean score of 5.18. Analysis using Wilcoxon matched pairs confirmed that this result was not statically significant $(p=.775)$. Despite this finding $(n=33), 97 \%$ of post-test respondents agreed with the statement that the PURPLE program "provides education about shaken baby syndrome in a timely manner," demonstrating a mean score of 6.44. Paralleling this outcome, $(n=33$, $97 \%$ ) of post-test respondents agreed that the PURPLE program "provides effective, meaningful education about shaken baby syndrome," with a mean score of 6.52. See Appendix B, Table 2 for frequency data.

\section{Perception of Educational Value:}

The majority $(n=44,95.7 \%)$ of pre-test respondents answered positively to "NICU Nurses should be providing shaken baby syndrome education during discharge teaching," with a mean score of 6.28 . Similarly, the majority $(n=33,97 \%)$ of post-test respondents agreed with a calculated mean score of 6.56. Despite an increase in the mean score, comparative analysis using the Wilcoxon matched-pairs test determined this change was not statically significant $(p=.731)$.

Similarly, the majority $(n=42,91.3 \%)$ of respondents on the pretest answered positively to "Providing education about shaken baby syndrome in the NICU is useful in preventing unplanned harm to an infant," with a mean score of 6.43. All post-test respondents $(n=34,100 \%)$ agreed or strongly agreed, with a calculated mean score of 6.56. Despite an increase in the mean score, comparative analysis using the Wilcoxon matched-pairs test deter-

\section{"The majority ( $n=33,97 \%)$ responded on the post-test with some degree of positivity, with responses indicating that the PURPLE program "was helpful in standardizing shaken baby syndrome education on our unit," with a mean score of 6.35."}

mined this change was not statically significant $(p=.705)$.

\section{Consistency of Educational Messages:}

The majority $(n=33,97 \%)$ responded on the post-test with some degree of positivity, with responses indicating that the PURPLE program "was helpful in standardizing shaken baby syndrome education on our unit," with a mean score of 6.35 .

\section{Appendix B}

Table 1 Study Sample

\begin{tabular}{|c|c|c|}
\hline Demographics of Study Sampl & & $\mathbf{n}$ \\
\hline Age & $20-30$ & 11 \\
\hline & $31-40$ & 17 \\
\hline & $41-50$ & 6 \\
\hline & $51-60$ & 12 \\
\hline & $61-70$ & 1 \\
\hline Gender & Male & 0 \\
\hline & Female & 46 \\
\hline & Other or prefer not to identify & 1 \\
\hline Education Level & Bachelor's Degree & 35 \\
\hline & Master's Degree & 10 \\
\hline & Doctoral Degree & 2 \\
\hline Years of experience as R.N. & $0-10$ & 27 \\
\hline & $11-20$ & 5 \\
\hline & $21-30$ & 9 \\
\hline & $30+$ & 6 \\
\hline Years of NICU experience & $0-10$ & 26 \\
\hline & $11-20$ & 8 \\
\hline & $21-30$ & 8 \\
\hline & $30+$ & 4 \\
\hline Shift & Day shift & 29 \\
\hline & Night shift & 6 \\
\hline Discharge teaching frequency & Seldom & 17 \\
\hline & Sometimes & 21 \\
\hline & Often & 9 \\
\hline
\end{tabular}

Discussion:

Among the six measurable objectives defined in this study, objectives two and three were met with statistical significance. The intervention effectively increased nursing confidence in delivering education about this sensitive topic area, evident by the statistically significant findings among pre-test and post-test responses designed to assess this parameter. The intervention also proved effective in increasing accessibility to available resources on SBS and AHT, similarly evident with statistically significant findings among comparative responses. Of note, pre-test survey responses related to the perceived value of SBS and AHT education infer participants considered education on this topic area valuable before this intervention, with post-test responses implying a heightened awareness of this value beyond these initial measures. Moreover, questions pertaining specifically to the Period of PURPLE Crying presented exclusively on the post-test were met with an overwhelmingly positive response, with the majority $(n=33,97 \%)$ of respondents agreeing that the intervention was useful in standardizing SBS education, providing meaningful, effective information on this topic area, and delivering SBS and AHT 
Table 2 Mean score and frequency summary of pre-and post-survey responses

\begin{tabular}{|c|c|c|c|c|c|c|}
\hline & $\begin{array}{l}\text { Pre-test } \\
\text { survey } \\
\text { mean } \\
\text { scores }\end{array}$ & Frequency (rank) & $\mathrm{n}$ & $\begin{array}{l}\text { Posttest } \\
\text { survey } \\
\text { mean } \\
\text { scores }\end{array}$ & Frequency (rank) & $\mathrm{n}$ \\
\hline $\begin{array}{l}\text { I feel knowledgeable when } \\
\text { it comes to shaken baby } \\
\text { syndrome }\end{array}$ & 5.70 & $\begin{array}{l}\text { (1)Strongly disagree } \\
\text { (2)Disagree } \\
\text { (3)Somewhat Disagree } \\
\text { (4)Neutral } \\
\text { (5)Somewhat Agree } \\
\text { (6)Agree } \\
\text { (7)Strongly Agree } \\
\text { Total } \\
\text { Missing }\end{array}$ & $\begin{array}{l}2 \\
0 \\
1 \\
0 \\
1 \\
3 \\
1 \\
9 \\
1 \\
2 \\
4 \\
7 \\
0\end{array}$ & 6.0 & $\begin{array}{l}\text { (1)Strongly disagree } \\
\text { (2)Disagree } \\
\text { (3)Somewhat Disagree } \\
\text { (4)Neutral } \\
\text { (5)Somewhat Agree } \\
\text { (6)Agree } \\
\text { (7)Strongly Agree } \\
\text { Total } \\
\text { Missing }\end{array}$ & $\begin{array}{l}2 \\
0 \\
0 \\
0 \\
3 \\
16 \\
13 \\
34 \\
0\end{array}$ \\
\hline $\begin{array}{l}\text { I feel comfortable } \\
\text { discussing shaken baby } \\
\text { syndrome with parents and } \\
\text { caregivers of NICU infants }\end{array}$ & 5.61 & $\begin{array}{l}\text { (1)Strongly disagree } \\
\text { (2)Disagree } \\
\text { (3)Somewhat Disagree } \\
\text { (4)Neutral } \\
\text { (5)Somewhat Agree } \\
\text { (6)Agree } \\
\text { (7)Strongly Agree } \\
\text { Total } \\
\text { Missing }\end{array}$ & $\begin{array}{l}1 \\
0 \\
3 \\
2 \\
9 \\
2 \\
2 \\
9 \\
4 \\
6 \\
1\end{array}$ & 6.24 & $\begin{array}{l}\text { (1)Strongly disagree } \\
\text { (2)Disagree } \\
\text { (3)Somewhat Disagree } \\
\text { (4)Neutral } \\
\text { (5)Somewhat Agree } \\
\text { (6)Agree } \\
\text { (7)Strongly Agree } \\
\text { Total } \\
\text { Missing }\end{array}$ & $\begin{array}{l}0 \\
0 \\
0 \\
1 \\
5 \\
13 \\
15 \\
34 \\
0\end{array}$ \\
\hline $\begin{array}{l}\text { NICU nurses should be } \\
\text { providing shaken baby } \\
\text { syndrome education during } \\
\text { discharge teaching }\end{array}$ & 6.28 & $\begin{array}{l}\text { (1)Strongly disagree } \\
\text { (2)Disagree } \\
\text { (3)Somewhat Disagree } \\
\text { (4)Neutral } \\
\text { (5)Somewhat Agree } \\
\text { (6)Agree } \\
\text { (7)Strongly Agree } \\
\text { Total } \\
\text { Missing }\end{array}$ & $\begin{array}{l}1 \\
0 \\
0 \\
1 \\
3 \\
1 \\
8 \\
2 \\
3 \\
4 \\
6 \\
1\end{array}$ & 6.56 & $\begin{array}{l}\text { (1)Strongly disagree } \\
\text { (2)Disagree } \\
\text { (3)Somewhat Disagree } \\
\text { (4)Neutral } \\
\text { (5)Somewhat Agree } \\
\text { (6)Agree } \\
\text { (7)Strongly Agree } \\
\text { Total } \\
\text { Missing }\end{array}$ & $\begin{array}{l}0 \\
0 \\
1 \\
0 \\
2 \\
7 \\
24 \\
34 \\
0\end{array}$ \\
\hline $\begin{array}{l}\text { Time constraints during } \\
\text { discharge are a major } \\
\text { barrier to discussing } \\
\text { shaken baby syndrome (i.e., } \\
\text { too much other education to } \\
\text { provide, not enough time, } \\
\text { too many other tasks to } \\
\text { accomplish) }\end{array}$ & 4.83 & $\begin{array}{l}\text { (1)Strongly disagree } \\
\text { (2)Disagree } \\
\text { (3)Somewhat Disagree } \\
\text { (4)Neutral } \\
\text { (5)Somewhat Agree } \\
\text { (6)Agree } \\
\text { (7)Strongly Agree } \\
\text { Total } \\
\text { Missing }\end{array}$ & $\begin{array}{l}0 \\
6 \\
7 \\
2 \\
1 \\
2 \\
1 \\
4 \\
6 \\
4 \\
7 \\
0\end{array}$ & 5.18 & $\begin{array}{l}\text { (1)Strongly disagree } \\
\text { (2)Disagree } \\
\text { (3)Somewhat Disagree } \\
\text { (4)Neutral } \\
\text { (5)Somewhat Agree } \\
\text { (6)Agree } \\
\text { (7)Strongly Agree } \\
\text { Total } \\
\text { Missing }\end{array}$ & $\begin{array}{l}3 \\
2 \\
2 \\
1 \\
6 \\
11 \\
9 \\
34 \\
0\end{array}$ \\
\hline
\end{tabular}




\begin{tabular}{|c|c|c|c|c|c|c|}
\hline $\begin{array}{l}\text { Providing education about } \\
\text { shaken baby syndrome in } \\
\text { the NICU is useful in } \\
\text { preventing unplanned harm } \\
\text { to an infant }\end{array}$ & 6.43 & $\begin{array}{l}\text { (1)Strongly disagree } \\
\text { (2)Disagree } \\
\text { (3)Somewhat Disagree } \\
\text { (4)Neutral } \\
\text { (5)Somewhat Agree } \\
\text { (6)Agree } \\
\text { (7)Strongly Agree } \\
\text { Total } \\
\text { Missing }\end{array}$ & $\begin{array}{l}0 \\
0 \\
0 \\
0 \\
4 \\
1 \\
8 \\
2 \\
4 \\
4 \\
6 \\
1\end{array}$ & 6.56 & $\begin{array}{l}\text { (1)Strongly disagree } \\
\text { (2)Disagree } \\
\text { (3)Somewhat Disagree } \\
\text { (4)Neutral } \\
\text { (5)Somewhat Agree } \\
\text { (6)Agree } \\
\text { (7)Strongly Agree } \\
\text { Total } \\
\text { Missing }\end{array}$ & \begin{tabular}{|l|}
0 \\
0 \\
0 \\
0 \\
0 \\
15 \\
19 \\
34 \\
0
\end{tabular} \\
\hline $\begin{array}{l}\text { I am aware of available } \\
\text { resources for families and } \\
\text { caregivers about shaken } \\
\text { baby syndrome }\end{array}$ & 3.85 & $\begin{array}{l}\text { (1)Strongly disagree } \\
\text { (2)Disagree } \\
\text { (3)Somewhat Disagree } \\
\text { (4)Neutral } \\
\text { (5)Somewhat Agree } \\
\text { (6)Agree } \\
\text { (7)Strongly Agree } \\
\text { Total } \\
\text { Missing }\end{array}$ & $\begin{array}{l}4 \\
8 \\
1 \\
0 \\
5 \\
1 \\
2 \\
5 \\
3 \\
4 \\
7 \\
0\end{array}$ & 5.97 & $\begin{array}{l}\text { (1)Strongly disagree } \\
\text { (2)Disagree } \\
\text { (3)Somewhat Disagree } \\
\text { (4)Neutral } \\
\text { (5)Somewhat Agree } \\
\text { (6)Agree } \\
\text { (7)Strongly Agree } \\
\text { Total } \\
\text { Missing }\end{array}$ & \begin{tabular}{|l|}
0 \\
0 \\
0 \\
0 \\
9 \\
17 \\
8 \\
34 \\
0
\end{tabular} \\
\hline $\begin{array}{l}\text { The Period of PURPLE } \\
\text { Crying Program was helpful } \\
\text { in standardizing shaken } \\
\text { baby syndrome education } \\
\text { on our unit }\end{array}$ & $\mathrm{NA}$ & NA & & 6.35 & $\begin{array}{l}\text { (1)Strongly disagree } \\
\text { (2)Disagree } \\
\text { (3)Somewhat Disagree } \\
\text { (4)Neutral } \\
\text { (5)Somewhat Agree } \\
\text { (6)Agree } \\
\text { (7)Strongly Agree } \\
\text { Total } \\
\text { Missing }\end{array}$ & \begin{tabular}{|l|}
0 \\
0 \\
0 \\
1 \\
2 \\
15 \\
16 \\
34 \\
0
\end{tabular} \\
\hline $\begin{array}{l}\text { The Period of PURPLE } \\
\text { Crying Program provides } \\
\text { effective, meaningful } \\
\text { education about shaken } \\
\text { baby syndrome }\end{array}$ & $\mathrm{NA}$ & $\mathrm{NA}$ & & 6.52 & $\begin{array}{l}\text { (1)Strongly disagree } \\
\text { (2)Disagree } \\
\text { (3)Somewhat Disagree } \\
\text { (4)Neutral } \\
\text { (5)Somewhat Agree } \\
\text { (6)Agree } \\
\text { (7)Strongly Agree } \\
\text { Total } \\
\text { Missing }\end{array}$ & \begin{tabular}{|l|}
0 \\
0 \\
0 \\
0 \\
1 \\
14 \\
18 \\
33 \\
1
\end{tabular} \\
\hline $\begin{array}{l}\text { The Period of PURPLE } \\
\text { Crying Program provides } \\
\text { education about shaken } \\
\text { baby syndrome in a timely } \\
\text { manner (i.e., able to provide } \\
\text { SBS education in a } \\
\text { reasonable amount of time } \\
\text { within discharge teaching) }\end{array}$ & NA & NA & & 6.44 & $\begin{array}{l}\text { (1)Strongly disagree } \\
\text { (2)Disagree } \\
\text { (3)Somewhat Disagree } \\
\text { (4)Neutral } \\
\text { (5)Somewhat Agree } \\
\text { (6)Agree } \\
\text { (7)Strongly Agree } \\
\text { Total } \\
\text { Missing }\end{array}$ & \begin{tabular}{|l|}
0 \\
0 \\
0 \\
1 \\
0 \\
16 \\
17 \\
34 \\
0 \\
\end{tabular} \\
\hline
\end{tabular}

NEONATOLOGY TODAY is interested in publishing manuscripts from Neonatologists, Fellows, NNPs and those involved in caring for neonates on case studies, research results, hospital news, meeting announcements, and other pertinent topics.

Please submit your manuscript to: LomaLindaPublishingCompany@gmail.com 


\begin{tabular}{|l|l|l|l|l|l|}
\hline & $\begin{array}{l}\text { Pre- } \\
\text { intervention } \\
\text { Survey }\end{array}$ & $\begin{array}{l}\text { Post- } \\
\text { intervention } \\
\text { Survey }\end{array}$ & Z & $\begin{array}{l}\text { Asymp. } \\
\text { Sig (2- } \\
\text { tailed). }\end{array}$ & $\begin{array}{l}\text { Statical } \\
\text { significance }\end{array}$ \\
\hline $\begin{array}{l}\text { I feel knowledgeable when it comes to shaken } \\
\text { baby syndrome }\end{array}$ & 5.70 & 6.0 & -.264 & .792 & Retain null \\
\hline $\begin{array}{l}\text { I feel comfortable discussing shaken baby } \\
\text { syndrome with parents and caregivers of NICU } \\
\text { infants }\end{array}$ & 5.61 & 6.24 & -2.412 & .016 & Reject null \\
\hline $\begin{array}{l}\text { NICU nurses should be providing shaken baby } \\
\text { syndrome education during discharge teaching }\end{array}$ & 6.28 & 6.56 & -.344 & .731 & Retain null \\
\hline $\begin{array}{l}\text { Time constraints during discharge are a major } \\
\text { barrier to discussing shaken baby syndrome } \\
\text { (i.e., too much other education to provide, not } \\
\text { enough time, too many other tasks to } \\
\text { accomplish) }\end{array}$ & 4.83 & 5.18 & -.286 & .775 & Retain null \\
\hline $\begin{array}{l}\text { Providing education about shaken baby } \\
\text { syndrome in the NICU is useful in preventing } \\
\text { unplanned harm to an infant }\end{array}$ & 6.43 & 6.56 & -.378 & .705 & Retain null \\
\hline $\begin{array}{l}\text { I am aware of available resources for families } \\
\text { and caregivers about shaken baby syndrome }\end{array}$ & 3.85 & 5.97 & -3.438 & $<.001$ & Reject null \\
\hline
\end{tabular}

\section{Appendix C}

Figure 1 The PURPLE program implementation map in the U.S.

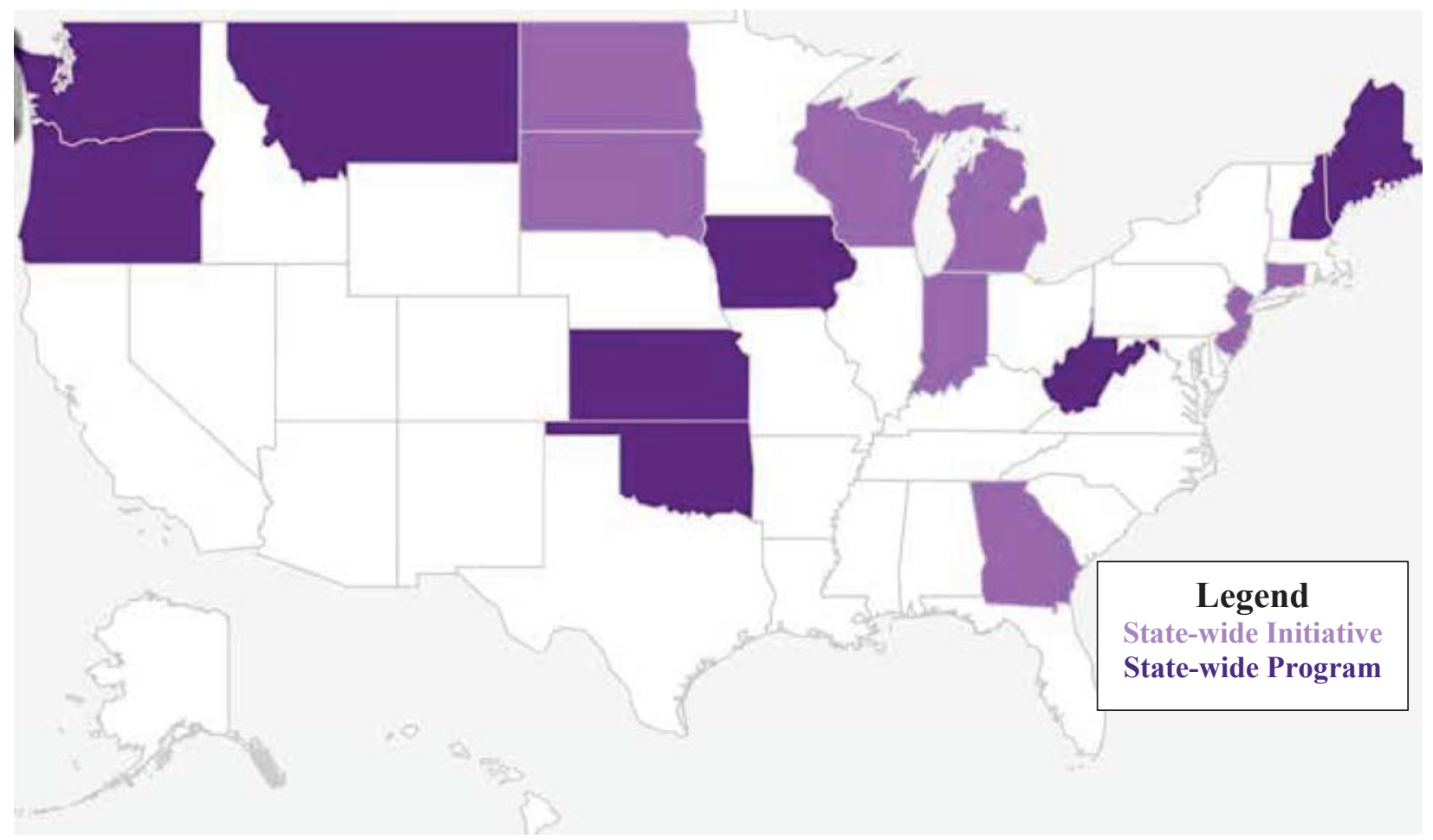


information promptly. This study supports the use of high-quality, standardized education to improve the quality and functionality of SBS/AHT education in the NICU setting; however, a larger sample would be advantageous in making more definitive inferences about these objectives.

\section{Time Constraints and Patient Education:}

An increase in the mean score from 4.83 to 5.18 on the pre-test to post-test responses when considering time constraints during discharge as a major barrier to discussing shaken baby syndrome may highlight an inherent conflict in healthcare. A study published in Clinical Nursing Studies (2017) examined the relationship between nurses' perceived barriers and patient education, finding that despite the importance nurses placed on patient education, work overload ranked highest among the barriers to delivering education (Livne et al., 2017) (7). Paralleling this notion, the findings of this study may imply that the use of the PURPLE program may offer nurses a means of making workload at discharge more manageable by embedding SBS and AHT education throughout the infant's hospitalization rather than solely discussing this topic

\section{"Paralleling this notion, the findings of} this study may imply that the use of the PURPLE program may offer nurses a means of making workload at discharge more manageable by embedding SBS and AHT education throughout the infant's hospitalization rather than solely discussing this topic at discharge."

at discharge. Further evaluation is necessary to make a definitive inference about this concept.

\section{Clinical Implications:}

Understanding that infants and children with risk factors such as prematurity, special needs, those under the age of six months that are often inconsolable, and multiple births place infants and young children at a higher risk for AHT and SBS and place further emphasis on the importance of utilizing this education program in the NICU setting, as many NICU graduates can be grouped into one of these aforementioned categories. This study may serve as a tool to reinforce and guide the adoption of the PURPLE program in this and other NICUs settings.

Beyond the NICU setting, considerations for how the widespread adoption of this program at the University of Chicago could impact the community should be acknowledged, as this hospital resides in an underserved community. Demographic evaluation of the medical center's surrounding area further emphasized the need for SBS and AHT education, as disparities prevalent within the community place families at high risk for unplanned infant harm.
According to the Journal of Research on Social Work Practice, "Low-income families are significantly more likely to have to contend with domestic violence, as poverty can act as a fueling factor in this type of conflict" (Slabbert, 2016, para. 1) (8). Data from the United States Census Bureau (2018) reported that $42.1 \%$ of households in Chicago are single-parent households, compared to $31 \%$ across Illinois and $32.7 \%$ across the U.S (Statistical Atlas, 2018 (9); U.S. Census Bureau, 2018) (10). This data also concluded that poverty affects $19.5 \%$ of households in Chicago, compared to $12.1 \%$ in Illinois and $11.8 \%$ across the U.S. (U.S. Census Bureau, 2018) (10). Understanding this data in relation to identified risk factors for AHT and SBS emphasizes the significance of incorporating high-quality, effective education into healthcare practices.

Strengths and Limitations:

"Given the commonality of resource challenges among hospitals coupled with the monetary challenges faced while implementing this study, barriers to the widespread use of this education program should be acknowledged and further explored."

Strengths of this study included the utilization of pre-test posttest design measures for assessing the quality of this education program. Survey responses were collected anonymously, thereby encouraging authentic results. Limiting factors of this study include the small sample size $(n=48)$ and a lower response rate on the post-test $(n=34)$. Other limitations included user error while entering their pre and post-test I.D. numbers into the surveys; this factor made matching survey responses more challenging. Despite these limitations, the study results inferred statistical significance with two of six measures, reinforcing the validity of this intervention.

\section{Future Research:}

Although the literature largely supports implementing this program, considerations to the challenges and barriers of implementing a large-scale education program in communities and hospitals alike must be addressed. A study in 2011 utilized cross-sectional surveys to evaluate current $\mathrm{AHT}$ educational practices and prevention programs among all North Carolina hospitals and birthing centers to further understand barriers to the adoption of a widespread AHT prevention program. This study reported that hospitals experiencing challenges in providing education on AHT were predominantly in rural communities, smaller hospitals, and those with limited access to abundant resources (Nocera et al., 2011) (5).

During this intervention, the cost to deliver the program was a barrier that nearly disrupted this intervention and would cause this

NEONATOLOGY TODAY is interested in publishing manuscripts from Neonatologists, Fellows, NNPs and those involved in caring for neonates on case studies, research results, hospital news, meeting announcements, and other pertinent topics.

Please submit your manuscript to: LomaLindaPublishingCompany@gmail.com 
program to be unsustainable in the long-term without adequate funding. Throughout this project, grant funding was explored to overcome this barrier and may be a real resource for achieving large-scale adoption of this program in the future. Given the commonality of resource challenges among hospitals coupled with the monetary challenges faced while implementing this study, barriers to the widespread use of this education program should be acknowledged and further explored.

A study conducted in British Columbia reviewing 64 cases of AHT events from 2002-2014 found that subsequent costs ranged from $\$ 1.6$ to $\$ 7.1$ million in healthcare spending and a societal cost of $\$ 354,359,080$. Comparatively, the PURPLE program costs approximately $\$ 5.00$ per infant (Beaulieu et al., 2019) (11). As healthcare continues to shift toward a preventative paradigm, this data strongly emphasizes the need to conduct future research in the U.S. surrounding cost-related barriers to implementing such prevention programs. Additionally, such research offers information to facilitate support from key stakeholders such as policymakers and health care providers, emphasizing that "...investing upstream in well-developed AHT prevention programs, such as PURPLE, not only promote child safety and health but also translates into avoided costs to society" (Beaulieu et al., 2019) (11). Future research must underpin cost-benefit analysis to prevent SBS and AHT to improve health outcomes and reduce future healthcare spending.

\section{Conclusion:}

The PURPLE program has been well-studied, with evidence suggesting that ongoing support for parents and caregivers can reduce hospital admissions associated with SBS and AHT and significantly impact the incidence of SBS and unplanned infant harm (Barr et al., 2019) (4). The purpose of this pilot study aimed to evaluate the nursing perception of the PURPLE program in a high-acuity NICU setting based on six measurable objectives. Two of the six Periods of PURPLE Crying objectives showed statistical significance supporting the important goals of this program. To continue improving upon the content and outcomes of the PURPLE program, ongoing evaluation across multivariate settings to further examine the multifaceted nature of unplanned infant harm is critical in the fight against this tragedy and to truly make a meaningful impact on this preventable, dynamic public health issue.

\section{References:}

1. Centers for Disease Control and Prevention. (n.d.). A Journalist's Guide to Shaken Baby Syndrome: A Preventable Tragedy. Retrieved from https://www.cdc.gov/violenceprevention/pdf/SBSMediaGuide.pdf

2. National Center on Shaken Baby Syndrome. (2021). PURPLE Crying. Retrieved from https://www.dontshake.org

3. National Center on Shaken Baby Syndrome. (2021). United States. Retrieved from https://www.dontshake.org/unitedstates

4. New York State Department of Health. (2010). Shaken Baby Syndrome: facts and figures. Retrieved from https://www. health.ny.gov/prevention/injury prevention/shaken baby syndrome/sbs fact sheet.htm
Readers can also follow NEONATOLOGY TODAY via our Twitter Feed @NEOTODAY

5. Barr, R. G., Barr, M., Rajabali, F. et al. (2019). Eight-year outcome of implementation of abusive head trauma prevention. Child Abuse \& Neglect, 84. doi.org/10.1016/j.chiabu.2018.07.004

6. Nocera, M., Shanahan, M., Murphy, R. A., Sullivan, K. M., Barr, M., Price, J., \& Zolotor, A. (2015). A statewide nurse training program for a hospital based infant abusive head trauma prevention program. Nurse Education in Practice, 16(1). https://doi.org/10.1016/j.nepr.2015.07.013

7. Barr, R. G., Rajabali, F., Aragon, M., Colbourne, M., \& Brant, R. (2015). Education About Crying in Normal Infants Is Associated with a Reduction in Pediatric Emergency Room Visits for Crying Complaints. Journal of Developmental \& Behavioral Pediatrics, 36(4), 252-257. DOI: 10.1097/ DBP.0000000000000156

8. Livne, Y., Peterfruend, L., \& Sheps, J. (2017). Barriers to patient education and their relationship to nurses' perceptions of patient education climate. Clinical Nursing Studies. Retrieved from http://www.sciedupress.com/journal/index. php/cns/article/view/11672

9. Slabbert, I. (2016). Domestic Violence and Poverty: Some Women's Experiences. The Journal of Research on Social Work Practice. Retrieved from https://journals.sagepub. com/doi/abs/10.1177/1049731516662321

10. Statistical Atlas. (2018, September $4^{\text {th }}$ ). Household Types by Place in the United States. Retrieved from https://statisticalatlas.com/United-States/Household-Types

11. United States Census Bureau. (2019). QuickFacts. Retrieved from https://www.census.gov/quickfacts/fact/table/ IL, chicagocityillinois, US/PST045218

12. Beaulieu, E., Rajabali, F., Zheng, A., Pike, I. (2019). The lifetime costs of pediatric abusive head trauma and a costeffectiveness analysis of the Period of PURPLE crying program in British Columbia, Canada Child Abuse \& Neglect, 97. DOI: 10.1016/j.chiabu.2019.104133

Disclosures: The authors have no disclosures:

\section{Acknowledgments:}

The money for this project was gifted as a donation by Dr. Veena Ramaiah to promote research on this topic area. We thank Dr. Ramaiah for making this contribution and this research project possible.

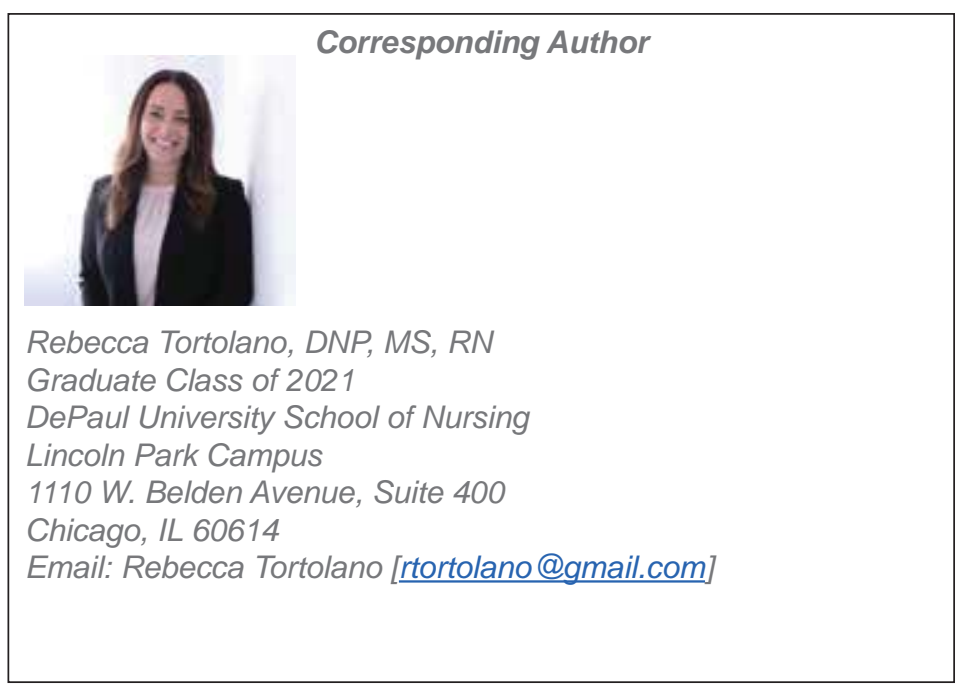



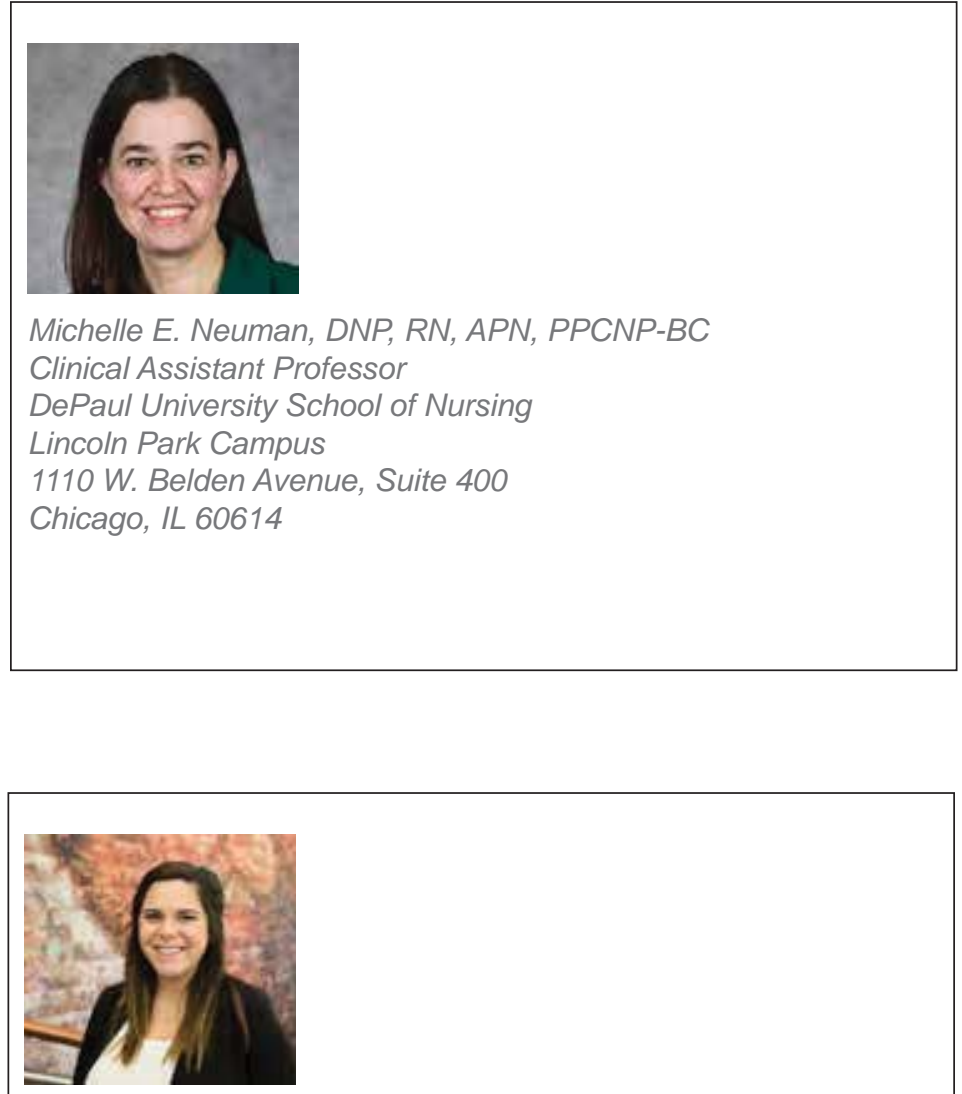

Shannon D. Simonovich, PhD, RN DePaul University School of Nursing Lincoln Park Campus

1110 W. Belden Avenue, Suite 400

Chicago, IL 60614

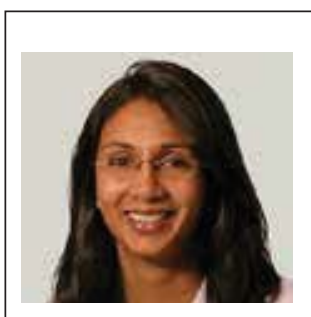

Faculty Mentor

Veena Ramaiah, MD

Associate Professor of Pediatrics

Child Advocacy and Protective Services (CAPS)

Department of Pediatrics

The University of Chicago \& Biological Sciences 5721 S. Maryland Avenue | Chicago, IL 60637 CAPS Office: 773-702-4900

Email: vramaiah@peds.bsd.uchicago.edu
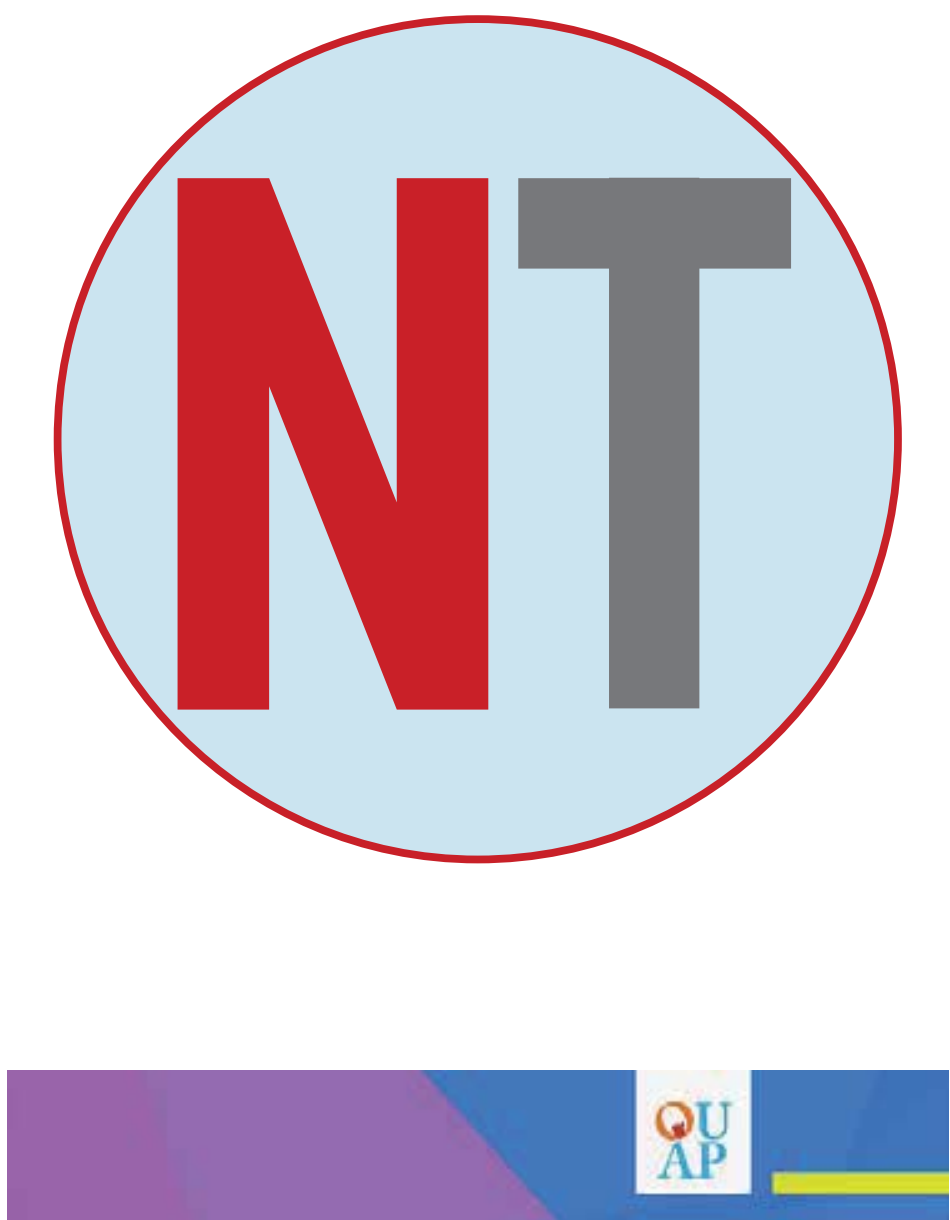

COMING SPRING 2021

ONCE UPON A PREEMIE ACADEMY On Demand

SIGN UP AND GET

Academy updates.

Training news.

YES, SIGN ME UP!

\section{EARN CME/CEU}

Learn more, visit onceuponapreemieacademy.com

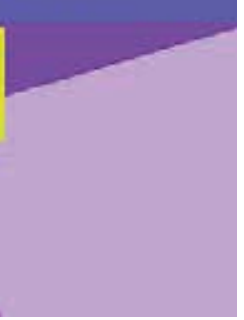

